\title{
Howland Award Presentation to Lewis A. Barness
}

\author{
GRANT MORROW III \\ Columbus Children's Hospital, Ohio State University, Columbus, OH 43205
}

It is a great privilege to introduce Dr. Lewis Abraham Barness, or as he is more affectionately known, the Chief, as the recipient of the 1993 John Howland Award. Lew was born in 1921, which, by the way, was a good year if one considers that Band-Aids were first introduced by Johnson and Johnson, the "Teapot Dome Scandal" had just begun, and Boston was still cleaning up from the great molasses flood in the northeast part of the city. According to Lew's first pediatrician (his mother), he was a beautiful baby. Lew agreed with her, and early in life he tried an unsuccessful modeling career. Although some might characterize his look as vacuous, in fact his parents were convinced that he was an early, deep thinker. He graduated from Harvard undergrad and then Harvard medical school in 1944, and he kept us safe by serving as a Captain in the United States Army-and he got it all done in 1 year. He then returned to Harvard for more training and in 1950 moved to the University of Pennsylvania. where he had his most productive academic years.

Lew has received multiple prestigious awards in the past, e.g. the Borden Award in 1972, the Goldberger Award in 1984, the Jacobi and St. Geme Awards in 1991, and finally the Howland Award this year. Dr. Barness is the only person to have won the grand slam of pediatric awards, i.e. the Jacobi, St. Geme, and Howland Awards. In 1987, the mayor of Tampa proclaimed a Lewis A. Barness Day-I might note that the mayor is no longer in public office. Also, Lew moved shortly thereafter to Wisconsin for very valid reasons, i.e. to marry his sweetheart. Enid tells me that he even wears his damn clip-on bowtie when taking a shower.

As a chairman, I realize how difficult it is to recruit triplethreat faculty members. Dr. Barness is one of the true triplethreat pediatricians. He had the luxury of learning his profession in a pre-MRI, pre-CAT scanner, pre-ultrasound, pre-chromosomal analysis era, i.e. a pre-technology era. As such, he had to rely on observation and the physical exam as essential tools. His six editions of Pediatric Physical Diagnosis are classics. With the entry of managed competition into the health care arena with its emphasis on decreasing the use of technology, his manual will reemerge as an essential one for future students. What goes around certainly comes around. Because he was the pediatrician for my two daughters, I had firsthand knowledge of how sensitive and competent he is as a physician.

As a teacher, he used the Socratic method and used it well. Of course, the students used to label it "Socratic terrorism." It was so Socratic that when Frank Oski was chief resident, he installed hemlock dispensers on Ward G. All of us tried to hide behind other students on chief rounds so we wouldn't be called upon and put on the spot. Probably most satisfying in Lew's thinking about his teaching accomplishments are the multiple awards that he has received from his students at the institutions with which he has been affiliated. He has an ineffable ability to instill intellectual excitement in his students as well as his junior faculty. As a scientist, Lew was always able to come up with a unique twist or question to a problem that opened up avenues to solve particular dilemmas. Take his first manuscript, for example, in which he looked at how Drosophila used glycogen and how they aged. His insights into the nutrition of childhood as well as into inborn errors of metabolism have helped innumerable children. Receiving the Howland Award is particularly appropriate for Dr. Barness because of John Howland's interests in the quantitative analytic techniques used to investigate diseases of children. Howland was particularly focused in acidosis, rickets, and calcium metabolism - all areas of intense interest for Dr. Barness. Lew's research ideas were spawned from dealing with patients, and it was his tenacity about asking questions and making certain that there were answers that has resulted in effective therapeutic interventions. One of the most impressive accomplishments of the Chief is that he is still very active and productive, as noted by his work in dietary nucleotides and their relation to the immune response. He is still actively collaborating with other investigators and publishing scientific articles.

In closing, I would like to read two paragraphs extracted from the preface of Lew's Festschrift, held in 1988:

No mention of Dr. Barness could be complete without commenting on his perpetual optimism, his skill in helping people reach their potential, his intense intellectual curiosity, his ability to inspire those around him to seek answers to the problems that confront us, his modesty, his very poor jokes, and his equally bad taste in clothes. His clip-on bow ties and his water pistol are as much a part of him as the smell of tobacco, his 'humble mumble,' his diagnostic acumen. and his store of information and misinformation.

For all this and more, we love him and we thank him for making the world a better place for children and for all of us to spend some time.

Chief, congratulations. 